\title{
Tight Coupling of Glaciecola spp. and Diatoms during Cold-Water Phytoplankton Spring Blooms
}

\author{
Markus von Scheibner ${ }^{1}$, Ulrich Sommer ${ }^{2}$ and Klaus Jürgens ${ }^{1 *}$ \\ ${ }^{1}$ Leibniz Institute for Baltic Sea Research Warnemünde, Rostock, Germany, ${ }^{2}$ Helmholtz Centre for Ocean Research, Kiel, \\ Germany
}

Early spring phytoplankton blooms can occur at very low water temperatures but they are often decoupled from bacterial growth, which is assumed to be often temperature controlled. In a previous mesocosm study with Baltic Sea plankton communities, an early diatom bloom was associated with a high relative abundance of Glaciecola sequences (Gammaproteobacteria), at both low $\left(2^{\circ} \mathrm{C}\right)$ and elevated $\left(8^{\circ} \mathrm{C}\right)$ temperatures, suggesting an important role for this genus in phytoplankton-bacteria coupling. In this study, the temperature-dependent dynamics of free-living Glaciecola spp. during the bloom were analyzed by catalyzed reporter deposition fluorescence in situ hybridization using a newly developed probe. The analysis revealed the appearance of Glaciecola spp. in this and in previous spring mesocosm experiments as the dominating bacterial

OPEN ACCESS

Edited by:

Jakob Pernthaler,

University of Zurich, Switzerland

Reviewed by:

Robert (Mike) McKay, Bowling Green State University, USA Ludwig Jardillier,

University of Paris-Sud, France

${ }^{*}$ Correspondence:

Klaus Jürgens

klaus.juergens@io-warnemuende.de

Specialty section:

This article was submitted to

Aquatic Microbiology,

a section of the journal

Frontiers in Microbiology

Received: 02 August 2016 Accepted: 05 January 2017 Published: 19 January 2017

Citation: von Scheibner M, Sommer U and Jürgens K (2017) Tight Coupling of Glaciecola spp. and Diatoms during

Cold-Water Phytoplankton Spring Blooms. Front. Microbiol. 8:27. doi: 10.3389/fmicb.2017.00027 clade during diatom blooms, with a close coupling between the population dynamics of Glaciecola and phytoplankton development. Although elevated temperature resulted in a higher abundance and a higher net growth rate of Glaciecola spp. ( $\left.Q_{10} \sim 2.2\right)$, their growth was, in contrast to that of the bulk bacterial assemblages, not suppressed at $2^{\circ} \mathrm{C}$ and showed a similar pattern at $8^{\circ} \mathrm{C}$. Independent of temperature, the highest abundance of Glaciecola spp. (24.0 $\pm 10.0 \%$ of total cell number) occurred during the peak of the phytoplankton bloom. Together with the slightly larger cell size of Glaciecola, this resulted in a $\sim 30 \%$ contribution of Glaciecola to total bacterial biomass. Overall, the results of this and previous studies suggest that Glaciecola has an ecological niche during early diatom blooms at low temperatures, when it becomes a dominant consumer of phytoplankton-derived dissolved organic matter.

Keywords: Glaciecola, phytoplankton, spring bloom, marine bacteria, temperature, Baltic Sea, CARD-FISH

\section{INTRODUCTION}

The predicted increase in surface temperatures of $2-5^{\circ}$ by the end of this century (IPCC, 2013) will lead to warmer oceans (Levitus, 2000), with important implications for pelagic communities and biotic interactions (Petchey et al., 1999; Burrows et al., 2011). For example, the differential impact of warming on autotrophic production and the consumption of dissolved organic matter (DOM) by heterotrophs induces a higher rate of bacterial degradation of phytoplankton-derived organic matter (Wohlers et al., 2009). At low temperatures, phytoplankton spring blooms can be temporally decoupled from bacterial degradation (Pomeroy and Deibel, 1986; Lignell et al., 1993; Bird and Karl, 1999), whereas rising water temperatures intensify phytoplankton-bacteria coupling and 
thereby enhance carbon flow into the microbial food web (Müren et al., 2005; Morán et al., 2006; Hoppe et al., 2008; Degerman et al., 2013). The mechanisms underlying these processes are poorly understood, although they probably depend on the ability of the bacterial assemblage to respond rapidly to the input of labile dissolved organic carbon (DOC) supplied by blooming phytoplankton (Pinhassi et al., 2004; Grossart et al., 2005; Sapp et al., 2007; Teeling et al., 2012). This has indeed been observed for bacteria belonging to Alteromonadales (Gammaproteobacteria), in which both cell abundance and transcriptional activities increase rapidly in response to DOC, particularly phytoplankton-derived organic carbon (Eilers et al., 2000; McCarren et al., 2010; Sarmento and Gasol, 2012; Beier et al., 2015). Although Alteromonadales are strongly grazed by bacterivorous protists (e.g., Beardsley et al., 2003), high proportional abundances have nonetheless been detected during marine phytoplankton spring blooms (Tada et al., 2011; Teeling et al., 2012), indicating the central role of these bacteria in the utilization of phytoplankton-derived DOC (Pedler et al., 2014).

The succession of dominant, free-living bacterial lineages during the proliferation of a phytoplankton spring bloom has not been well-studied at high taxonomic resolution, with a few exceptions (Teeling et al., 2012). Most studies quantitatively examined the bacterial succession during the phytoplankton blooms, using relatively broad phylogenetic probes such as those for Bacteroidetes, Gammaproteobacteria, and Roseobacter in marine environments (Alderkamp et al., 2006; Tada et al., 2011; Sintes et al., 2013) and for Actinobacteria, Bacteroidetes, and Betaproteobacteria in limnic systems (Zeder et al., 2009; Eckert et al., 2012). To our knowledge, no study has quantified the species- or genus-level dynamics of the dominant bacteria during the development of a phytoplankton spring bloom. The identification of these bacterial taxa would enable a more detailed investigation of their role during early phytoplankton spring blooms, when low water temperatures are thought to otherwise suppress most bacterial activities (Pomeroy and Deibel, 1986).

Mesocosm studies have shown that warming results in a tighter phytoplankton-bacterial coupling and an enhanced carbon flow into the microbial food web (Hoppe et al., 2008; Wohlers et al., 2009; Wohlers-Zöllner et al., 2012; von Scheibner et al., 2014). Reduced bacterial development in the colder treatments is due to a combination of lower growth rates and relatively temperature-insensitive protist grazing pressure (von Scheibner et al., 2014). In this study, we were particularly interested in following the growth dynamics of Glaciecola spp. (Alteromonadaceae, Gammaproteobacteria), identified as a dominant taxa in a previous mesocosm study carried out during early phytoplankton bloom conditions. We also examined how the growth of these bacteria is affected by an increase in temperature. The population dynamics of Glaciecola spp., were investigated by using a newly developed, specific catalyzed reporter deposition fluorescence in situ hybridization (CARDFISH) probe to analyze the experimental phytoplankton blooms that developed at low (in situ: $\sim 2^{\circ} \mathrm{C}$ ) and high $\left(\Delta+6^{\circ} \mathrm{C}\right.$ $\sim 8^{\circ} \mathrm{C}$ ) temperatures in the mesocosm experiment reported in von Scheibner et al. (2014). The results showed that Glaciecola spp. dominated the free-living bacterial assemblages in the mesocosms, despite intense grazing pressure, and thus presumably play an important role in carbon processing during diatom blooms, both at low and at elevated temperatures.

\section{MATERIALS AND METHODS}

\section{Experimental Design and Sampling}

The experiment was performed within the priority program AQUASHIFT (Sommer et al., 2007), using 12 indoor mesocosms maintained in four climate chambers at the GEOMAR (Kiel, Germany) from 6 February to 26 March 2008, as previously described in detail with respect to the phytoplankton development and experimental setup (Lewandowska and Sommer, 2010), biogeochemistry (Biermann et al., 2014), and microbial response (von Scheibner et al., 2014). Briefly, the 12 mesocosms, each with a volume of $1400 \mathrm{~L}$, were filled simultaneously with unfiltered brackish seawater from the Kiel Fjord (Baltic Sea) and thus contained the natural winter/spring community (in situ temperature of $4.1^{\circ} \mathrm{C}$ ). They were then incubated at either $\sim 2.0^{\circ} \mathrm{C}\left(=\Delta 0^{\circ} \mathrm{C}\right.$; low temperature $)$ or $\sim 8.0^{\circ} \mathrm{C}\left(=\Delta 6^{\circ} \mathrm{C}\right.$; high temperature $)$. The experiment also crosslinked the two temperature scenarios with three different light conditions. However, since the latter had no significant effect on either phytoplankton or bacterial parameters, the respective mesocosms were pooled such that six replicate mesocosms were available for each temperature (Lewandowska and Sommer, 2010; von Scheibner et al., 2014).

Samples used to determine bacterial abundance were fixed with $2 \%$ (final concentration) formaldehyde, filtered onto $0.2-\mu \mathrm{m}$ polycarbonate filters (Whatman), stained with $4^{\prime}, 6$ diamidino-2-phenylindole (DAPI), and then counted on a Zeiss Axioplan epifluorescence microscope at $1000 \times$ magnification. For bacterial biomass estimations, the area of the DAPIstained bacterial cells was measured with the program CellIP (Olympus). The results were projected to cell volume by assuming a cylindrical shape for the cells and then transforming that value into biomass using the equation: $\mathrm{fg} \mathrm{C}$ cell $^{-1}=133.754 \times \mathrm{V}^{0.438}$, according to Romanova and Sazhin (2010).

For the enumeration of heterotrophic nanoflagellates (HNFs), the samples were filtered onto $0.8-\mu \mathrm{m}$ black polycarbonate filters (Whatman), stained with DAPI, and counted using an epifluorescence microscope (Axioskop2 mote plus, Zeiss). Biovolumes were calculated from the mean cell diameter and converted to carbon using a conversion factor of $220 \mathrm{fg} \mathrm{C} \mathrm{cm}^{3}$ (for details, see von Scheibner et al., 2014).

The Glaciecola probe was also used to examine samples from a AQUASHIFT mesocosm experiment performed at the GEOMAR in 2006. The experimental setup was similar and the temperature range was the same ( $\Delta 0^{\circ} \mathrm{C}$ to $\Delta+6^{\circ} \mathrm{C}$ in four temperature steps). However, the duplicate mesocosms were exposed to only one light condition (Sommer et al., 2007). The $0.2-\mu \mathrm{m}$ polycarbonate filters $(3.0-\mu \mathrm{m}$ prefiltered) obtained in that study were stored at $-80^{\circ} \mathrm{C}$. For the purposes of the present work, we selected filters representing each of the eight mesocosms at the chlorophyll- $a$ (Chl a) peak of the diatom-dominated phytoplankton bloom. 
To assess the in situ abundance of Glaciecola spp. during early spring bloom conditions in the Baltic Sea using the CARD-FISH probe, eight surface samples were collected during a research cruise with the $R / V$ Alkor between 4 and 11 March 2009. Water samples $(30-50 \mathrm{ml})$ obtained from two stations in the Gulf of Finland, two stations in the central Baltic Sea (Gotland Basin), and four stations in the southern Baltic Sea (near the coast of Germany) were filtered onto $0.2-\mu \mathrm{m}$ polycarbonate filters and stored first at $-50^{\circ} \mathrm{C}$ on the ship and then later, in the institute, at $-80^{\circ} \mathrm{C}$, until processing.

\section{CARD-FISH and Evaluation of the GC1252 Probe}

In a previous mesocosm experiment designed to study a phytoplankton spring bloom at low temperatures, nearly fulllength 16S rRNA gene sequences were retrieved from clone libraries (von Scheibner et al., 2014). One of the dominant sequences occurring during the peak of the bloom belonged to the bacterial genus Glaciecola.

A CARD-FISH probe highly specific for the Glaciecola operational taxonomic unit (OTU) was designed using the probe design tool in the ARB program suite (Ludwig et al., 2004). The resulting probe, GC1252 (5'AGGGATGCAAACTGGTGACAGT-3'), had five outgroup hits against Glaciecola and 30 hits within Glaciecola according to SILVA TestProbe 3.0, effective Jan. 2016 (Supplementary Table S2). It was named GC1252 in reference to Glaciecola (GC) and the banding position with respect to the 16S RNA of Escherichia coli (1252). A recent study revealed that the genus Glaciecola comprises Glaciecola and Paraglaciecola (Shivaji and Reddy, 2014), but probe GC1252 targets a small clade within the genus Glaciecola, including the cultivated strains Glaciecola pallidula and Glaciecola nitratireducens and one uncultured Antarctic sea ice bacterium within Paraglaciecola (Supplementary Table S1). Probe GC1252 was validated using a Glaciecola pallidula culture (Bowman et al., 1998) as a positive control and Alteromonas macleodii (Baumann et al., 1972), Colwellia psychrerythraea (Deming et al., 1988), and Escherichia coli (Migula, 1895) cultures as negative controls. To determine the optimal formamide concentration in the hybridization buffer, hybridizations were performed within a formamide concentration range of $0-60 \%$ using $5 \%$ increments. The optimal formamide concentration for the detection of the Glaciecola clade was 55\%; at this concentration a positive signal was obtained only with the positive control strain Glaciecola pallidula. The phylogenetic tree of the genus Glaciecola was constructed based on the full-length $16 \mathrm{~S}$ rRNA sequences of selected strains within the SILVA database SSU_NR_123 (Quast et al., 2013) using the maximum-likelihood analysis (PHYML, DNA) provided in the ARB 6 program suite (Ludwig et al., 2004) and including clonal sequences determined in the mesocosm experiment (von Scheibner et al., 2014). Colwellia psychrerythraea served as the outgroup taxa.

The enumeration of Glaciecola sp. and other free-living bacteria by CARD-FISH was based on samples previously filtered onto $0.2-\mu \mathrm{m}$ polycarbonate filters $(3.0-\mu \mathrm{m}$ prefiltered), as described in detail in von Scheibner et al. (2014). CARDFISH was performed according to a slightly modified version of the protocol of Pernthaler et al. (2002). Briefly, the samples were hybridized at $35^{\circ} \mathrm{C}$ for at least $2 \mathrm{~h}$ or overnight with the following horseradish-peroxidase-labeled probes (50 pmol $\mu^{-1}$, biomers.net, Germany) prepared in hybridization buffer (1:150) containing 55\% formamide: EUB338 I-III (Daims et al., 1999), GAM42a + GAM42a-C (Manz et al., 1992), GC1252 (this study), and, as the negative control, non-EUB (Wallner et al., 1993) (Table 1). The hybridized cells were counted by automated image acquisition using an epifluorescence microscope in combination with a Colibri LED unit (Axioskop2 mote plus, Zeiss, Germany) according to Zeder et al. (2009). The acquired images were quality-controlled using the software AIQC, developed by Zeder et al. (2009). The images were then manually checked; only samples with at least 1000 positive DAPI counts were used for further analysis.

Additionally, we combined microautoradiography with CARD-FISH (micro-CARD-FISH) to evaluate the activity of the Glaciecola clade based on its incorporation of $\left[{ }^{3} \mathrm{H}\right]$-leucine, following the protocol described in Teira et al. (2004). In brief, $4 \mathrm{ml}$ of unfiltered water collected from each mesocosm during the phytoplankton bloom peak was incubated with $\left[{ }^{3} \mathrm{H}\right]$-leucine (20 nM final concentration) at the in situ temperature for $2 \mathrm{~h}$. Incubations were terminated by the addition of formaldehyde (2\% final concentration). All samples were filtered onto $0.2-\mu \mathrm{m}$ polycarbonate filters (Millipore, Darmstadt, Germany) softly bedded on cellulose acetate filters (Millipore, $0.45 \mu \mathrm{m}$ ), rinsed with Milli-Q water, dried, and stored at $-20^{\circ} \mathrm{C}$ until further processing for microautoradiography as described in Teira et al. (2004).

TABLE 1 | Overview of the CARD-FISH (catalyzed reporter deposition fluorescence in situ hybridization) probes used in this study.

\begin{tabular}{llllr}
\hline Probe & Target & Sequence $\left(\mathbf{5}^{\prime} \mathbf{-} \mathbf{3}^{\prime}\right)$ & Formamide (\%) \\
\hline EUB338 I-III & Most Bacteria & GCTGCCTCCCGTAGGAGT & 55 & Reference \\
& & GCAGCCACCCGTAGGTGT & & Daims et al., 1999 \\
GAM42a & Gammaproteobacteria & GCCTCCCCACATCGTIT & 55 & Manz et al., 1992 \\
GAM42a-C & Competitor for GAM42a & AGGGAUGCAAACUGGUGACAGU & 55 & Manz et al., 1992 \\
GC1252 & Glaciecola clade & AGGGATGCAAACTGGTGACAGT & 55 & This study \\
Non-EUB & Negative control & ACTCCTACGGGAGGCAGC & 55 & Wallner et al., 1993
\end{tabular}




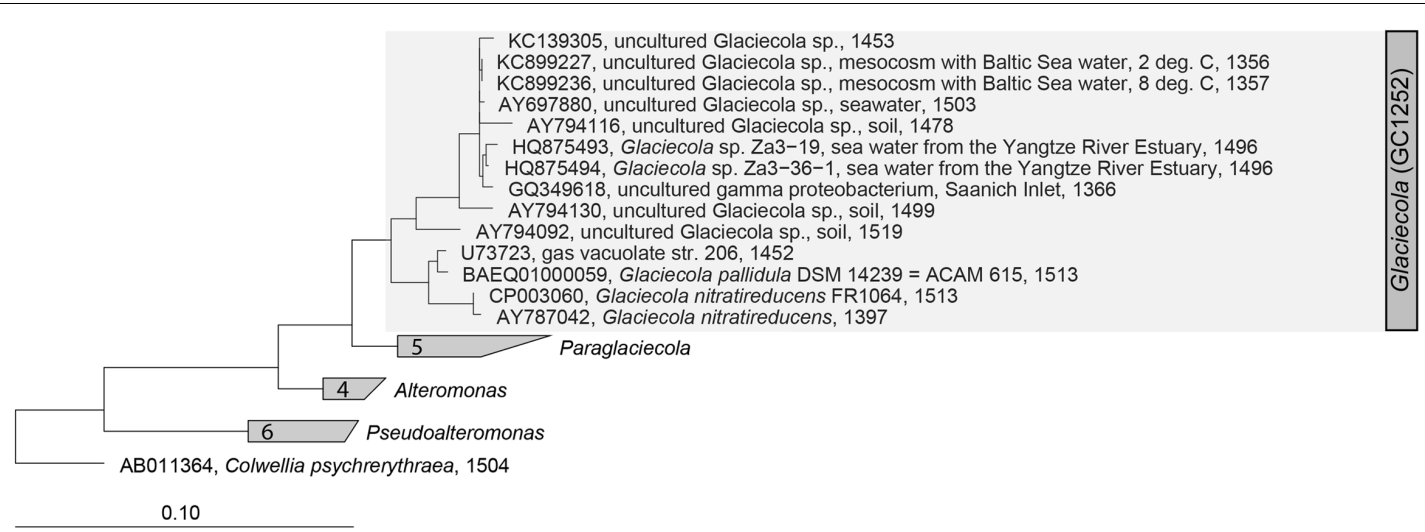

FIGURE 1 | Maximum likelihood (PHYML, DNA) tree of the genus Glaciecola within the family Alteromonadaceae (Gammaproteobacteria). The specific, newly developed CARD-FISH (catalyzed reporter deposition fluorescence in situ hybridization) probe GC1252 targets a narrow clade within the genus Glaciecola (shaded in gray).

\section{Calculation of Growth Rates and Statistical Analysis}

Both the net growth rates of the individual bacterial groups detected by the CARD-FISH probes and the total cell numbers were calculated with respect to the changes in cell abundance over time. Net growth rates were calculated according to Peters (2002), assuming exponential growth. The growth rates during the period of increasing cell abundance, defined as between the start (day 8) and peak (day 18) of the phytoplankton bloom, were calculated separately for each mesocosm (six replicate mesocosms per temperature). This period covered five time points for the determination of total bacterial abundance and at least four time points for the detection of Glaciecola (GC1252), Gammaproteobacteria (Gam 42a), and total Bacteria (EUBI-III). These net growth rates can be regarded as minimum estimates and would probably be higher with more frequent sampling. However, the major bacterial increase that occurred in parallel with bloom development was similarly covered at the low and high temperatures, which therefore enabled comparisons of the results. The temperature sensitivity of a given process can be described by its $Q_{10}$ value, which is the factorial increase in the rate of that process in response to an increase in temperature of $10^{\circ} \mathrm{C}$. The $\mathrm{Q}_{10}$ value was calculated for the increase in cell abundance of the different bacterial groups, and the significance of the temperature effects was evaluated using an independent sample $t$-test.

\section{RESULTS}

During the peak of the phytoplankton bloom, bacterial community composition, analyzed by $16 \mathrm{~S}$ rRNA Sangersequenced clone libraries, was clearly dominated by Gammaproteobacteria under the low $\left(\sim 2.0^{\circ} \mathrm{C}\right)$ and high $\left(\sim 8.0^{\circ} \mathrm{C}\right)$ temperature regimes, as previously reported (von Scheibner et al., 2014). The most abundant OTU was that of a Glaciecola sp. closely related to Glaciecola sp. HTCC2999 (98\%) and to Glaciecola pallidula (96\%), which accounted for $57 \%$ and
$44 \%$ of the total clones in the colder and warmer treatments, respectively (von Scheibner et al., 2014). A precise cellular quantification of Glaciecola spp. using the newly designed probe GC1252 was now possible. However, while GC1252 was primarily designed to detect the abundant Glaciecola sequence, it is also able to target a narrow clade containing 30 taxa within the genus Glaciecola (Figure 1; Supplementary Tables S1 and S2), including two OTUs previously found in the clone libraries (von Scheibner et al., 2014). In our mesocosm experiment, GC1252positive cells were present as uniform free-living, relatively large rod-shaped cells (Supplementary Figure S1). The measured area of Glaciecola spp. cells was on average 34\% larger than that of all bacterial cells, resulting in a $\sim 43 \%$ higher biomass per cell.

Phytoplankton spring blooms with similar growth patterns developed in all 12 mesocosms, but significant differences were consistently observed between the two temperature scenarios $\left(\Delta 0^{\circ} \mathrm{C}\right.$ and $\Delta+6^{\circ} \mathrm{C}$ ). These included the lower $\mathrm{Chl} a$ maximum and its advanced onset (4-6 days) with warming (Figure 2) (Lewandowska and Sommer, 2010; Biermann et al., 2014). The phytoplankton bloom was dominated by diatoms, with Skeletonema costatum as the dominant species under warmer conditions ( $55 \pm 8 \%$ of total phytoplankton biomass vs. $19 \pm 5 \%$ under colder conditions) and Thalassiosira rotula as the most abundant species under colder conditions $(39 \pm 6 \%$ of total phytoplankton biomass vs. to $3 \pm 1 \%$ under warmer conditions) (Lewandowska and Sommer, 2010). Bacterial abundance was strongly enhanced during the phytoplankton bloom at the higher temperature, reaching $2.15 \pm 0.08 \times 10^{6}$ cells ml $^{-1}$ at its peak

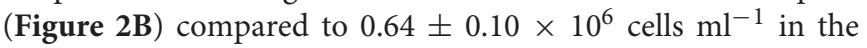
colder treatment (Figure 2A).

The population dynamics of Glaciecola spp. (GC1252-positive cells), especially during the exponential growth phase, were followed by analyzing samples from all 12 mesocosms over the entire course of the phytoplankton spring bloom (Figure 2). Glaciecola spp. were of low abundance before the bloom, constituting only $1-2 \%$ of the total free-living bacterial cells (DAPI-stained cells), except in mesocosm IV (5.7\%). A strong increase in Glaciecola spp. was first observed in parallel with 


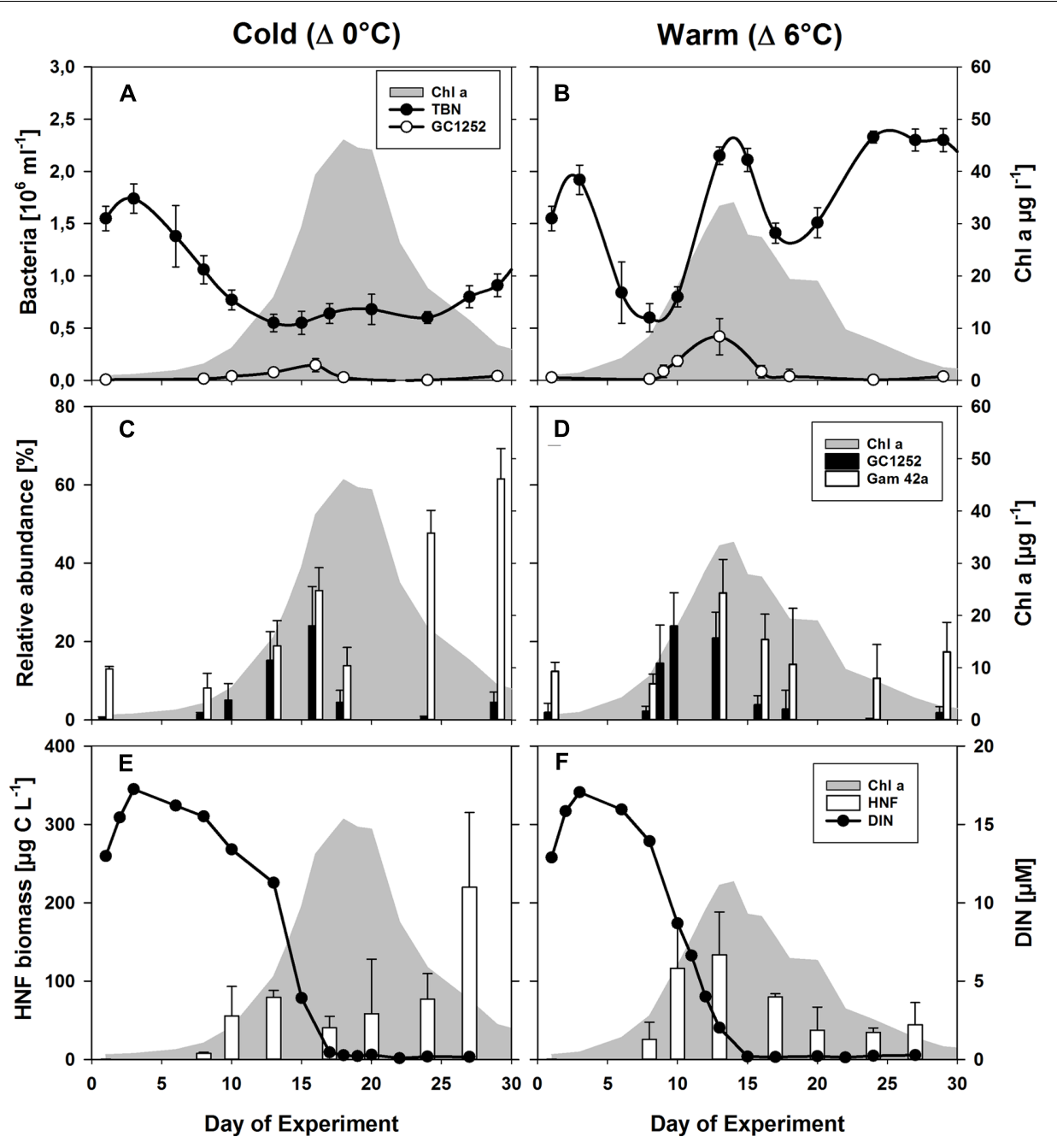

FIGURE 2 | Phytoplankton and bacterial development during the mesocosm experiment. (A,B) Changes in the abundances of total bacterial numbers (TBN) and of cells detectable by CARD-FISH using the probes GC1252 (Glaciecola) during the phytoplankton blooms (shaded in gray) for the low ( $\Delta 0^{\circ} \mathrm{C} \sim 2{ }^{\circ} \mathrm{C}$ ) and high $\left(\triangle 6^{\circ} \mathrm{C} \sim 8^{\circ} \mathrm{C}\right.$ ) temperature scenarios. (C,D) Relative abundance of cells detectable by FISH using the probes Gam42a (Gammaproteobacteria) and GC1252

(Glaciecola). (E,F) Estimated heterotrophic nanoflagellate (HNF) biomass (von Scheibner et al., 2014) and dissolved inorganic nitrogen (DIN). From Biermann et al. (2014).

the developing phytoplankton bloom, although it was somewhat slower in the colder treatments (Figure 2). In the warmer treatments, the relative abundance of Glaciecola spp. developed in parallel with that of the whole bacterial assemblage, increasing within 2 days from $2.2 \pm 1.3 \%\left(0.13 \pm 0.0810^{5}{\left.\text { cells } \mathrm{ml}^{-1}\right)}^{-1}\right.$ on day 8 to $24.0 \pm 8.5 \%\left(1.85 \pm 0.5110^{5}\right.$ cells $\left.\mathrm{ml}^{-1}\right)$ on day 10 (Figure 2). In the colder treatments, Glaciecola spp. increased even though total bacterial numbers stayed constant or in some cases decreased. The observed increase occurred

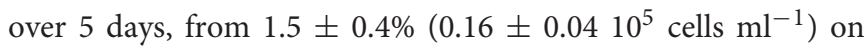
day 8 to $15.2 \pm 7.3 \%\left(0.77 \pm 0.3110^{5}\right.$ cells $\left.\mathrm{ml}^{-1}\right)$ on day 13 (Figure 2).

The resulting doubling times of Glaciecola spp., calculated from the increase in cell numbers, were significantly ( $t$-test: $p=0.019$ ) lower in the warmer than in the colder treatments $(9.6 \pm 1.5$ vs. $23.0 \pm 8.0 \mathrm{~h})$, with corresponding maximal growth rates $(\mu)$ of 1.77 day $^{-1}$ and 1.10 day $^{-1}$, respectively. Based on the appraised doubling times of the different temperature treatments, the $\mathrm{Q}_{10}$ value for Glaciecola spp. was 2.2.

Heterotrophic nanoflagellate biomass increased in synchrony with the growth of the phytoplankton bloom and with Glaciecola spp. abundance (Figure 2). In the warmer treatments, HNF biomass rose from $26 \pm 8 \mu \mathrm{g} \mathrm{C} \mathrm{L}^{-1}$ on day 8 to $116 \pm 56 \mu \mathrm{g} \mathrm{C}$ $\mathrm{L}^{-1}$ on day 10 , whereby the Glaciecola spp. population increased

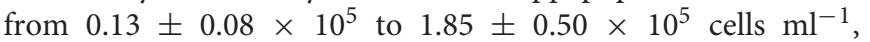
respectively. In the colder treatments, HNF biomass increased from $22 \pm 1 \mu \mathrm{g} \mathrm{C} \mathrm{L^{-1 }}$ on day 8 to $54 \pm 9 \mu \mathrm{g} \mathrm{C} \mathrm{L}^{-1}$ on day 13 , whereby the Glaciecola spp. population increased from $0.16 \pm 0.04 \times 10^{5}$ to $0.77 \pm 0.31 \times 10^{5}$ cells $\mathrm{ml}^{-1}$. Hence, the maximum calculated grazing pressure occurred during the highest Glaciecola spp. abundance in the warmer treatments and shortly before the Glaciecola spp. peak in the colder treatments. 
During the phytoplankton bloom peak, the average number of total free-living bacterial cells was clearly higher in the warmer $\left(2.15 \pm 0.08 \times 10^{6}\right.$, at day 13$)$ than in the colder $\left(0.64 \pm 0.10 \times 10^{6}\right.$, at day 17$)$ mesocosms, with $1.74 \pm 0.49 \times 10^{6}$ cells $(85 \pm 7 \%)$ and $0.36 \pm 0.05 \times 10^{6}$ cells $(60 \pm 10 \%)$ attributable to the Bacteria probe (EUB I-III), respectively. At the same time, Gammaproteobacteria predominated, with a relative abundance in the warmer and colder treatments of $32 \pm 9$ and $33 \pm 6 \%$ of total free-living cells, respectively. Within this bacterial group, Glaciecola spp. accounted for $65 \pm 13$ and $69 \pm 30 \%$ of total Gammaproteobacteria in the warmer and colder treatments, respectively (Figures 2 and 3 ). The maximum abundances of Glaciecola spp. were detected in the warmer treatments at the phytoplankton peak $\left(4.20 \pm 1.73 \times 10^{5}\right.$ cells, day 13) and in the colder treatments 1 day earlier $\left(1.45 \pm 0.82 \times 10^{5}\right.$ cells, day 16). Although Glaciecola spp. achieved higher growth rates at warmer temperatures, its proportions at the phytoplankton peak were similar such that the difference between the two temperature scenarios was not significant ( $t$-test: $p=0.578$ ).

Micro-CARD-FISH analysis revealed that during the phytoplankton bloom peak, 65\% of Bacteria (EUB I-III) showed activity, based on their incorporation of $\left[{ }^{3} \mathrm{H}\right]$-leucine (data not shown). However, no $\left[{ }^{3} \mathrm{H}\right]$-leucine uptake was detected for Glaciecola spp. despite the fact that at least 200 cells that hybridized with probe GC1252 were microscopically examined. The inability of Glaciecola spp. to incorporate $\left[{ }^{3} \mathrm{H}\right]$-leucine implies that cell production by these bacteria was not included in the overall calculations of bacterial production. The free-living life style of Glaciecola spp. during the phytoplankton bloom peak was confirmed by micro CARD-FISH analysis with non-prefiltered water, as none of the cells attached to algae or detritus particles.

According to the measured cell sizes of Glaciecola spp., the mean cell volume of these bacteria was $\sim 40 \%$ higher than the average bacterial cell volume. Glaciecola spp. reached its highest biomass in the warmer treatments on day 10 and in the colder treatments at the phytoplankton peak, which occurred on day 16 (34 \pm 12 and $29 \pm 19 \%$ of total bacterial biomass, respectively). During the proliferation phase of the phytoplankton bloom, total primary production was clearly lower in the warmer than in the colder treatment. By contrast, bacterial production was strongly enhanced at the warmer temperature, as evidenced by the $\sim 60 \%$ higher measured bacterial production (BPm) and the nearly two-fold higher estimated production rate of Glaciecola spp. $\left(\mathrm{BP}_{\mathrm{GC}}\right)$ (Table 2). This enhanced bacterial activity under warmer conditions in combination with the reduced autotrophic production resulted in clearly higher ratios of $\mathrm{BPm}$ and $\mathrm{BP}_{\mathrm{GC}}$ to PP (Table 2).

The collapse of the phytoplankton spring bloom was initiated by nutrient depletion (Biermann et al., 2014). This was paralleled by a sharp decline in the abundance of Glaciecola spp. within 2 days, to $0.38 \pm 0.67 \times 10^{5}$ cell $\mathrm{ml}^{-1}(2.7 \pm 4.9 \%)$ and $0.30 \pm 0.20 \times 10^{5}$ cell $\mathrm{ml}^{-1}(4.5 \pm 3.0 \%)$ on day 18 in the warmer and colder treatments, respectively. In both, Glaciecola abundances remained low until the end of the experiment (Figure 2). Interestingly, the dynamics of

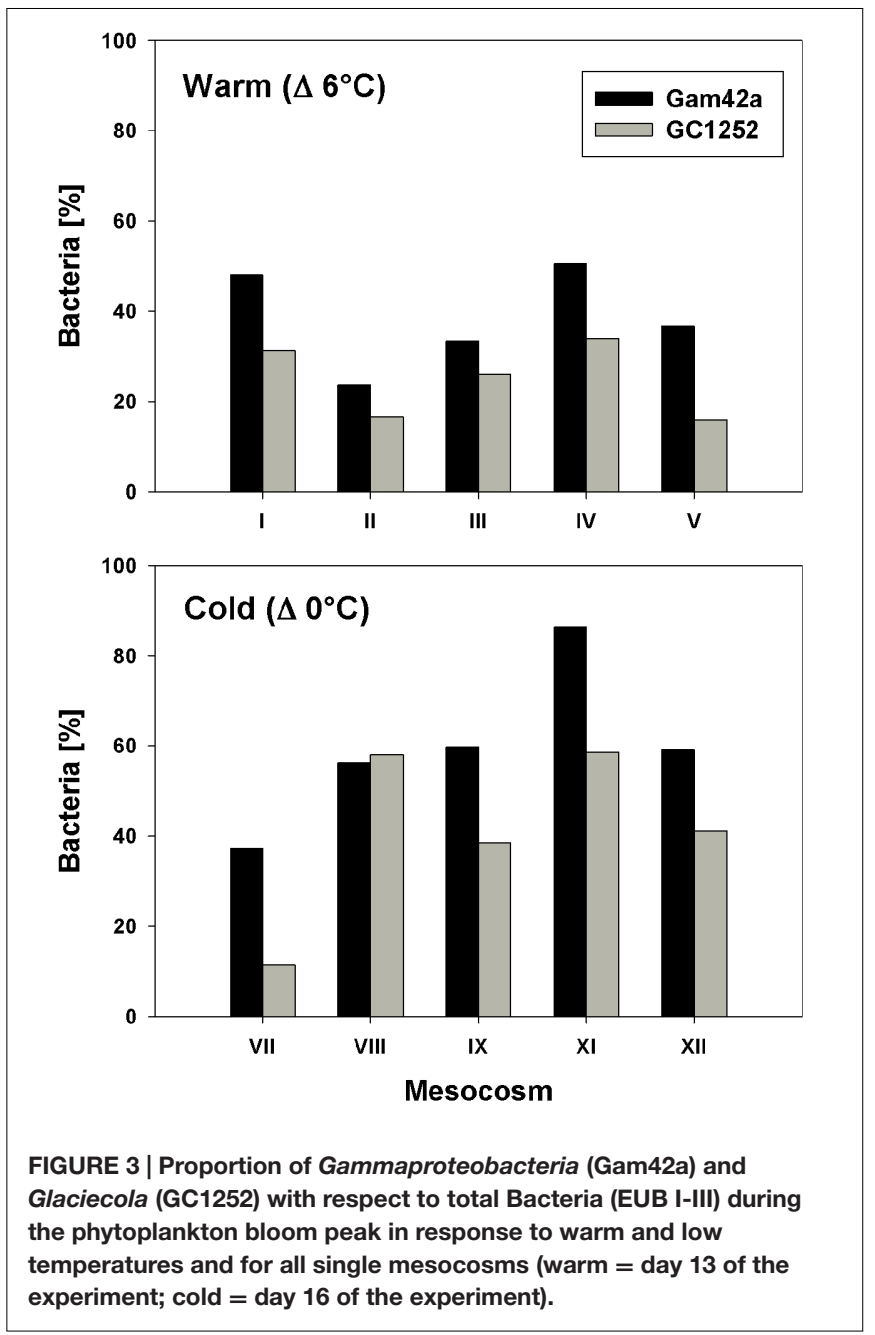

Glaciecola spp. were much more pronounced than those of total Gammaproteobacteria, whose abundance remained high or even increased further (in the colder) until the end of the experiment. The pattern was indicative of a succession within this bacterial group during the degradation of the phytoplankton bloom.

The occurrence of Glaciecola spp. was also determined in spring bloom mesocosm experiments performed in 2006 (Sommer et al., 2007; Hoppe et al., 2008; Wohlers et al., 2009) by again applying probe GC1252 to samples filtered and stored in the same way as in the above-described experiment (Table 3). Thus, pre-bloom, bloom, and post-bloom samples from mesocosms in which water temperatures were maintained at $\Delta 0^{\circ} \mathrm{C}+\Delta 2^{\circ} \mathrm{C}+\Delta 4^{\circ} \mathrm{C}+\Delta 6^{\circ} \mathrm{C}$ were examined for Glaciecola spp. The results confirmed the high proportion of Glaciecola spp. in all treatments, as evidenced by abundances of $2-12 \%$ $(5.0 \pm 3.5 \%)$ of all bacterial cells close to the phytoplankton bloom peak and independent of the water temperature (Table 3 ).

To examine the abundance of Glaciecola spp. under comparable in situ conditions in the Baltic Sea, surface water samples were collected in brackish areas from the Gulf of Finland to the southern Baltic Sea during early 
TABLE 2 | Primary production (PP), measured bacterial production $\left(\mathrm{BP}_{\mathrm{m}}\right)$, estimated bacterial production of Glaciecola spp. (BP $\mathrm{GC}$ ), and the resulting

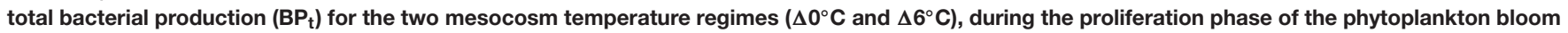
(days 8-13 for $\Delta^{\circ} 6 \mathrm{C}$; days 10-16 for $\Delta^{\circ} 0 \mathrm{C}$ ) and the phytoplankton bloom peak.

\begin{tabular}{|c|c|c|c|c|c|c|c|}
\hline & PP & $\mathrm{BP}_{\mathrm{m}}$ & $\mathrm{BP}_{\mathrm{GC}}$ & $\mathbf{B P}_{\mathbf{T}}$ & Ratio[BP $\left.\mathrm{GC}_{\mathrm{G}} / \mathrm{BP}_{\mathrm{m}}\right]$ & Ratio[BP $\left.{ }_{\mathrm{GC}} / \mathrm{PP}\right]$ & Ratio[BP $\left.{ }_{\mathrm{T}} / \mathrm{PP}\right]$ \\
\hline Cold (bloom) & $1528 \pm 566$ & $118 \pm 6$ & $33 \pm 4$ & $151 \pm 8$ & $0.28 \pm 0.03$ & $0.02 \pm 0.01$ & $0.11 \pm 0.05$ \\
\hline Cold (bloom peak) & $322 \pm 123$ & $25 \pm 5$ & $9 \pm 4$ & $33 \pm 9$ & $0.34 \pm 0.14$ & $0.03 \pm 0.02$ & $0.13 \pm 0.07$ \\
\hline Warm (bloom) & $1038 \pm 241$ & $193 \pm 31$ & $63 \pm 30$ & $256 \pm 60$ & $0.32 \pm 0.01$ & $0.06 \pm 0.02$ & $0.25 \pm 0.03$ \\
\hline Warm (bloom peak) & $267 \pm 78$ & $43 \pm 8$ & $13 \pm 6$ & $59 \pm 13$ & $0.30 \pm 0.10$ & $0.05 \pm 0.03$ & $0.23 \pm 0.09$ \\
\hline
\end{tabular}

The resulting ratios of BP to PP were calculated as indicators of carbon flow from phyto- to bacterioplankton.

spring (March), when water temperatures are low $(-0.3$ to $\left.3.1^{\circ} \mathrm{C}\right)$. In the northern and central Baltic Sea, phytoplankton biomass was very low $\left(<50 \mu \mathrm{g} \quad \mathrm{C} \mathrm{L}^{-1}\right)$ and Glaciecola spp. was not detected. At the more southern stations, sites of an ongoing diatom-dominated phytoplankton bloom, the maximum phytoplankton biomass detected was $347 \mu \mathrm{g} \mathrm{C} \mathrm{\textrm {L } ^ { - 1 }}$ and Skeletonema costatum was the dominant phytoplankton taxa (von Scheibner et al., in preparation). At these southern stations, Glaciecola spp. was detectable but only in low numbers, accounting for $0.01-0.3 \%$ of the total DAPI-stained prokaryotic cells.

\section{DISCUSSION}

The successful enumeration of Glaciecola cells with the CARD-FISH probe GC1252 revealed a positive correlation between Glaciecola spp. abundance and Chl a during the exponential growth phase of the phytoplankton spring blooms in all treatments. Glaciecola spp. represented a large part of the bacterial community under both colder and warmer temperatures and dominated the free-living bacterial community. Probe GC1252 was primarily designed to detect a dominant OTU belonging to Glaciecola, as among the tested probes the GC1252 sequence showed the highest specificity within the smallest phylogenetic range in combination with the lowest outgroup hits (Supplementary Table S2). However, GC1252 not only targets the dominant Glaciecola OTU (up to $55 \%$ of total clones) but also another Glaciecola OTU present within the clone libraries at low abundance ( $\sim 1 \%$ of total clones). Nonetheless, the highly abundant Glaciecola species probably largely accounts for the reported results.

A temperature increase of $6^{\circ} \mathrm{C}$ enhanced the growth of Glaciecola spp., but the general growth pattern at warmer and colder temperatures were remarkably similar. It consisted of a rapid buildup of the populations that paralleled phytoplankton bloom development and the rapid collapse of the Glaciecola population after phytoplankton numbers had peaked (Figure 2). Adaptation by the genus Glaciecola to low temperatures and cold environments is suggested by a number of studies. A recent metagenomic analysis of the genus Glaciecola identified several cold-adapted mechanisms in the pan-genome that would allow the survival and growth of this genus at low temperatures (Qin et al., 2014). Although cold environments (e.g., in polar regions) seem to be the favored habitat of Glaciecola (Bowman et al., 1998; Nichols et al., 1999; van Trappen et al., 2004; Zhang et al.,
TABLE 3 | Maximum proportion of Glaciecola spp. with respect to total free-living cells, water temperature, and $\mathrm{Chl}$ a concentration in two different AQUASHIFT experiments and in the Baltic Sea during March 2009 at two stations where an early phytoplankton bloom was detected.

\begin{tabular}{lccc}
\hline Sample & $\begin{array}{c}\text { Temperature } \\
{\left[{ }^{\circ} \mathbf{C}\right]}\end{array}$ & $\begin{array}{c}\text { Chl a } \\
{\left[\mu \mathrm{g} \mathrm{I}^{-1}\right]}\end{array}$ & $\begin{array}{c}\text { Max proportion } \\
{[\%]}\end{array}$ \\
\hline AQUASHIFT mesocosms 2006 & 2.4 & 52 & 10.6 \\
& 4.4 & 56 & 3.6 \\
& 6.4 & 39 & 3.2 \\
AQUASHIFT mesocosms 2008 & 8.4 & 48 & 11.5 \\
& 2.4 & 42.5 & 34.9 \\
Baltic Sea, March 2009 & 8.4 & 34.5 & 36.4 \\
& 2.4 & & \\
& 3.2 & $\sim 9.5$ & 0.3 \\
\end{tabular}

For the Baltic Sea, Chl a was estimated from phytoplankton biomass based on a Chl a:phytoplankton carbon ratio of 1:40 (Cloern et al., 1995).

2006; Prabagaran et al., 2007), its members have also been found in Mediterranean coastal waters (Alonso-Sáez et al., 2007) and during a phytoplankton spring bloom in the North Sea (Teeling et al., 2012).

Glaciecola, and the family Alteromonadaceae as a whole, is generally not an abundant member of bacterioplankton communities, but their abundance can rapidly increase following the input of labile phytoplankton-derived DOC (Eilers et al., 2000; Grossart et al., 2005; Mou et al., 2008; McCarren et al., 2010; Gómez-Consarnau et al., 2012). This is probably due to an up-regulation of metabolic genes associated with DOM utilization at optimal substrate concentrations (Tada et al., 2011). This conclusion is also supported by a metatranscriptomic study, in which, after the addition of diatom-derived DOM, Glaciecola sp. (HTCC2999) dominated carbohydrate metabolism pathways (Beier et al., 2015). Furthermore, growth experiments with specific DOC compounds revealed the generalist nature of some phylotypes in the genus Glaciecola, based on their ability to respond to a broad range of carbon compounds (e.g., Glaciecola pallidula), and the specialist nature of others, as demonstrated by their use of a highly restricted number of carbon compounds (e.g., pyruvate) (Gómez-Consarnau et al., 2012). Although the DOM composition in our mesocosms was not determined, the two dominant diatom species, Skeletonema costatum and Thalassiosira rotula, most likely 
provided exudated DOC compounds during their active growth phase and thereby effectively generated an ecological niche for Glaciecola. In a previous mesocosm experiment with a similar experimental setup and phytoplankton composition, DOC dynamics and composition were itemized in detail (Engel et al., 2011). In that study, large increases in the percentages of deoxysugars (mainly rhamnose and fucose) were registered before the peak of the bloom and decreased thereafter (Engel et al., 2011). This pattern is remarkably similar to that of the growth dynamics of Glaciecola and indicative of specific DOC-compounds as regulating factors for these bacteria. A limited labile organic carbon supply does not account for the sharp decline in Glaciecola spp. after the phytoplankton peak, since during this phase of the bloom both total DOC and mono-/polysaccharide concentrations strongly increased (Biermann et al., 2014). Rather, the changes in the DOC composition from the active phytoplankton growth phase to the nutrient-limited phytoplankton decline were likely to have regulated the growth of Glaciecola spp. in our experiment and suggest an ecological niche of this group. This conclusion is supported by batch-culture experiments in which, among the free-living bacterial community, the presence of Gammaproteobacteria (Glaciecola and Pseudoalteromonas) was associated exclusively with the growth phases of the diatoms Thalassiosira rotula and Skeletonema costatum (Sapp et al., 2007).

In addition to the assumed changes in DOC composition after the phytoplankton bloom peak, reinforced grazing pressure exerted by small protists may have contributed to the decline in Glaciecola spp. abundance (Figures 2E,F). Gammaproteobacteria, and especially Alteromonas, are particularly vulnerable to protist grazing, as indicated in previous studies that demonstrated selective flagellate grazing on these large, metabolically active bacteria (Beardsley et al., 2003; Worden et al., 2006; Allers et al., 2007). The high rate of phytoplankton-derived DOC utilization by Glaciecola and subsequent grazing by bacterivores may constitute a characteristic link in the microbial food web during phytoplankton blooms.

Considering the above-average cell size of Glaciecola spp., its estimated biomass was about one-third of the total bacterial biomass, indicating an enormous impact of one narrow bacterial clade (or even one species) on carbon processing during the proliferative stage of the phytoplankton bloom. Interestingly, given that Glaciecola spp. proved to be incapable of $\left[{ }^{3} \mathrm{H}\right]$-leucine uptake, we no doubt highly underestimated bacterial production (von Scheibner et al., 2014). The inability of certain bacterial taxa to incorporate leucine or thymidine, both of which are used to assess bacterial productivity, is not unusual (Salcher et al., 2013). For this experiment, we estimate that total BP was at least 30\% higher during the bloom proliferation phase than during other phases (Table 2) since Glaciecola spp. was not covered by the leucine incorporation approach.

In situ growth rates were calculated based on the net increase in Glaciecola spp. abundance and therefore can be considered as lower-end estimates, because mortality due to grazing or viral lysis was not considered. Further, a more frequent sampling interval might have provided slightly higher growth rate estimates. However, the maximum calculated growth rates were similar to those determined in earlier batch culture experiments at low temperatures. For example, the generation time of the isolate Glaciecola punicea was $\sim 13 \mathrm{~h}$ at $8^{\circ} \mathrm{C}$ and $\sim 26 \mathrm{~h}$ at $2^{\circ} \mathrm{C}$ (Nichols et al., 1999). A comparable net growth rate $\left(\mu \approx 2.3\right.$ day $\left.^{-1}\right)$ was determined for the family Alteromonadaceae in incubation experiments, and it increased after the reduction of predators $\left(\mu \approx 4.0 \mathrm{day}^{-1}\right)$ and viruses $\left(\mu \approx 5.8\right.$ day $^{-1}$ ) (Ferrera et al., 2011). The high growth rates at cold temperatures may explain the ability of Alteromonadaceae to rapidly proliferate such that it dominates microbial communities exposed to a substrate pulse (Eilers et al., 2000; Beardsley et al., 2003; Alonso-Sáez et al., 2007; Mou et al., 2008). Substrate pulses, such as occur during phytoplankton blooms, can promote the expansion of specific bacterial populations (Pernthaler and Amann, 2005), which in turn can briefly but strongly impact carbon processing and transfer to higher trophic levels and thereby disrupt the general seasonal bacterial succession (Lindh et al., 2015).

The detection of a substantial abundance of Glaciecola spp. also in a previous mesocosm experiment that included a diatom bloom at low water temperature (Table 3) suggests that our results exemplify a general pattern. The relative low abundance of Glaciecola spp. in the southern Baltic Sea during an early spring bloom is a deviation from this pattern (Table 3) but might have resulted from the relatively low phytoplankton biomass or differences in phytoplankton community composition. Thus, only intensive and detailed studies can reveal natural seasonal bacterial succession involving transiently expanding bacterial taxa. For example, Teeling et al. (2012) carried out a detailed investigation of the bacterioplankton response to a diatom bloom in the North Sea. Their results suggested that algal substrate availability provides a series of ecological niches in which specialized populations, such as the Gammaproteobacteria Glaciecola spp. and Reinekea spp., can increase (Teeling et al., 2012).

Since the original description of the genus Glaciecola as comprising gram-negative, aerobic, psychrophilic slightly halophilic bacteria (Bowman et al., 1998), there have been many extensions and modifications (van Trappen et al., 2004; Baik et al., 2006; Zhang et al., 2006; Shivaji and Reddy, 2014). However, most species seem to be psychrophilic, including those responsible for the results of this study, which achieved high in situ net growth rates at a low temperature of $\sim 2^{\circ} \mathrm{C}$. This is in accordance with the lack of a significant temperature effects on the relative abundance of Glaciecola spp. Also the relatively low $\mathrm{Q}_{10}$ value of 2.2 is within the normal range of temperature-accelerated bacterial growth (Kirchman et al., 2009). Remarkably, despite higher grazing pressure from HNF, the growth rate of Glaciecola spp. at the low temperature was high $\left(\sim 1.10 \mathrm{day}^{-1}\right)$, in contrast to that of the total bacterial community $\left(\sim 0.4\right.$ day $\left.^{-1}\right)$.

Yet, besides direct temperature effects, the growth dynamic of Glaciecola spp. determined in this experiment could also have been influenced by biotic interactions within a complex food-web as well as by differences in phytoplankton 
community composition or grazer abundance (Lewandowska and Sommer, 2010; Aberle et al., 2012; Winder et al., 2012). Overall, the coincidence of the high growth rate and abundance of Glaciecola spp. with the onset of the phytoplankton bloom indicates a tight coupling between blooming diatoms and Glaciecola spp. Moreover, this relationship provides evidence of a key role of cold-adapted Glaciecola spp. in the processing of phytoplankton-derived DOC during the proliferation of phytoplankton at low water temperatures. Increasing the experimental temperature did not substantially change this relationship, as Glaciecola spp. remained the dominant bacterial taxa also after warming, although other bacterial groups gained in importance as well (von Scheibner et al., 2014). Whether Glaciecola is replaced by other taxa at temperatures higher than that tested here and how this dynamic is regulated by the interplay of substrate composition, grazing, and viral lysis remain to be determined. It will also be interesting to compare our results with those obtained in other marine environments (e.g., those with higher salinity), where different bacterial taxa dominate the respective carbon flow during early phytoplankton blooms.

\section{REFERENCES}

Aberle, N., Bauer, B., Lewandowska, A. M., Gaedke, U., and Sommer, U. (2012). Warming induces shifts in microzooplankton phenology and reduces time-lags between phytoplankton and protozoan production. Mar. Biol. 159, 2441-2453. doi: 10.1007/s00227-012-1947-0

Alderkamp, A. C., Sintes, E., and Herndl, G. J. (2006). Abundance and activity of major groups of prokaryotic plankton in the coastal North Sea during spring and summer. Aquat. Microb. Ecol. 45, 237-246. doi: 10.3354/ame045237

Allers, E., Gómez-Consarnau, L., Pinhassi, J., Gasol, J. M., Šimek, K., and Pernthaler, J. (2007). Response of Alteromonadaceae and Rhodobacteriaceae to glucose and phosphorus manipulation in marine mesocosms. Environ. Microbiol. 9, 2417-2429. doi: 10.1111/j.1462-2920.2007.01360.x

Alonso-Sáez, L., Balagué, V., Sà, E. L., Sánchez, O., González, J. M., Pinhassi, J., et al. (2007). Seasonality in bacterial diversity in north-west Mediterranean coastal waters: assessment through clone libraries, fingerprinting and FISH. FEMS Microbiol. Ecol. 60, 98-112. doi: 10.1111/j.1574-6941.2006.00276.x

Baik, K. S., Park, Y.-D., Seong, C. N., Kim, E. M., Bae, K. S., and Chun, J. (2006). Glaciecola nitratireducens sp. nov., isolated from seawater. Int. J. Syst. Evol. Microbiol. 56, 2185-2188. doi: 10.1099/ijs.0.64330-0

Baumann, L., Baumann, P., Mandel, M., and Allen, R. D. (1972). Taxonomy of aerobic marine eubacteria. J. Bacteriol. 110, 402-429.

Beardsley, C., Pernthaler, J., Wosniok, W., and Amann, R. (2003). Are readily culturable bacteria in coastal North Sea waters suppressed by selective grazing mortality? Appl. Environ. Microbiol. 69, 2624-2630. doi: 10.1128/AEM.69.5. 2624-2630.2003

Beier, S., Rivers, A. R., Moran, M. A., and Obernosterer, I. (2015). The transcriptional response of prokaryotes to phytoplankton-derived dissolved organic matter in seawater. Environ. Microbiol. 17, 3466-3480. doi: 10.1111/ 1462-2920.12434

Biermann, A., Engel, A., and Riebesell, U. (2014). Changes in organic matter cycling in a plankton community exposed to warming under different light intensities. J. Plankton Res. 36, 658-671. doi: 10.1093/plankt/fbu005

Bird, D. F., and Karl, D. M. (1999). Uncoupling of bacteria and phytoplankton during the austral spring bloom in Gerlache Strait, Antarctic Peninsula. Aquat. Microb. Ecol. 19, 13-27. doi: 10.3354/ame019013

Bowman, J. P., McCammon, S. A., Brown, J. L., and McMeekin, T. A. (1998). Glaciecola punicea gen. nov., sp. nov. and Glaciecola pallidula gen. nov., sp. nov. Psychrophilic bacteria from Antarctic sea-ice habitats. Int. J. Syst. Bacteriol. 48, 1213-1222. doi: 10.1099/ijs.0.065409-0

\section{AUTHOR CONTRIBUTIONS}

MvS, US, KJ designed the experiment. MvS performed the sampling and analysis. MvS, US, KJ wrote the manuscript.

\section{ACKNOWLEDGMENTS}

We thank T. Hansen and A. Ludwig for technical support, A. Lewandowska for contributing phytoplankton data, and A. Biermann for nutrient and Chl $a$ data. We also appreciate the assistance of R. Koppe in bacterial counting and the technical support for automated microscopy provided by M. Zeder. This project was funded by Priority Program 1162 of the German Research Foundation (DFG) and funding to KJ (JU 367/7-2).

\section{SUPPLEMENTARY MATERIAL}

The Supplementary Material for this article can be found online at: http://journal.frontiersin.org/article/10.3389/fmicb. 2017.00027/full\#supplementary-material

Burrows, M. T., Schoeman, D. S., Buckley, L. B., Moore, P., Poloczanska, E. S., Brander, K. M., et al. (2011). The pace of shifting climate in marine and errestrial ecosystems. Science 334, 652-655. doi: 10.1126/science.12 10288

Cloern, J. E., Grenz, C., and Vidergar-Lucas, L. (1995). An empirical model of the phytoplankton chlorophyll/carbon ratio-The conversion factor between productivity and growth rate. Limnol. Oceanogr. 40, 1313-1321. doi: 10.4319/ lo.1995.40.7.1313

Daims, H., Brühl, A., Amann, R., Schleifer, K.-H., and Wagner, M. (1999). The domain-specific probe EUB338 is insufficient for the detection of all bacteria. Development and evaluation of a more comprehensive probe set. Syst. Appl. Microbiol. 22, 434-444.

Degerman, R., Dinasquet, J., Riemann, L., Sjöstedt de Luna, S., and Andersson, A. (2013). Effect of resource availability on bacterial community responses to increased temperature. Aquat. Microb. Ecol. 68, 131-142. doi: 10.3354/ ame01609

Deming, J. W., Somers, L. K., Straube, W. L., Swartz, D. G., and Macdonell, M. T. (1988). Isolation of an obligately barophilic bacterium and description of a new genus, Colwellia gen. nov. Syst. Appl. Microbiol. 10, 152-160. doi: 10.1016/S0723-2020(88)80030-4

Eckert, E. M., Salcher, M. M., Posch, T., Eugster, B., and Pernthaler, J. (2012). Rapid successions affect microbial $\mathrm{N}$-acetyl-glucosamine uptake patterns during a lacustrine spring phytoplankton bloom. Environ. Microbiol. 14, 794-806. doi: 10.1111/j.1462-2920.2011.02639.x

Eilers, H., Pernthaler, J., and Amann, R. (2000). Succession of pelagic marine bacteria during enrichment. A close look at cultivation-induced shifts. Appl. Environ. Microbiol. 66, 4634-4640.

Engel, A., Händel, N., Wohlers, J., Lunau, M., Grossart, H.-P., Sommer, U., et al. (2011). Effects of sea surface warming on the production and composition of dissolved organic matter during phytoplankton blooms. Results from a mesocosm study. J. Plankton Res. 33, 357-372. doi: 10.1093/plankt/ fbq122

Ferrera, I., Gasol, J. M., Sebastián, M., Hojerová, E., and Koblízek, M. (2011). Comparison of growth rates of aerobic anoxygenic phototrophic bacteria and other bacterioplankton groups in coastal Mediterranean waters. Appl. Environ. Microbiol. 77, 7451-7458. doi: 10.1128/AEM.00208-11

Gómez-Consarnau, L., Lindh, M. V., Gasol, J. M., and Pinhassi, J. (2012). Structuring of bacterioplankton communities by specific dissolved organic carbon compounds. Environ. Microbiol. 14, 2361-2378. doi: 10.1111/j.14622920.2012.02804.x 
Grossart, H.-P., Levold, F., Allgaier, M., Simon, M., and Brinkhoff, T. (2005). Marine diatom species harbour distinct bacterial communities. Environ. Microbiol. 7, 860-873. doi: 10.1111/j.1462-2920.2005.00759.x

Hoppe, H.-G., Breithaupt, P., Walther, K., Koppe, R., Bleck, S., Sommer, U., et al. (2008). Climate warming in winter affects the coupling between phytoplankton and bacteria during the spring bloom. A mesocosm study. Aquat. Microb. Ecol. 51, 105-115. doi: 10.3354/ame01198

IPCC (2013). Intergovernmental Panel on Climate Change 2013 - The Physical Science Basis. Cambridge: Cambridge University Press.

Kirchman, D. L., Morán, X. A. G., and Ducklow, H. (2009). Microbial growth in the polar oceans - role of temperature and potential impact of climate change. Nat. Rev. Microbiol. 7, 451-459. doi: 10.1038/nrmicro2115

Levitus, S. (2000). Warming of the world ocean. Science 287, 2225-2229. doi: 10.1126/science.287.5461.2225

Lewandowska, A. M., and Sommer, U. (2010). Climate change and the spring bloom. A mesocosm study on the influence of light and temperature on phytoplankton and mesozooplankton. Mar. Ecol. Prog. Ser. 405, 101-111.

Lignell, R., Heiskanen, A.-S., Kuosa, H., Gundersen, K., Kuuppo-Leinikki, P., Pajuniemi, R., et al. (1993). Fate of a phytoplankton spring bloom: sedimentation and carbon flow in the planktonic food web in the northern Baltic. Mar. Ecol. Prog. Ser. 94, 239-252. doi: 10.3354/meps094239

Lindh, M. V., Sjostedt, J., Andersson, A. F., Baltar, F., Hugerth, L. W., Lundin, D., et al. (2015). Disentangling seasonal bacterioplankton population dynamics by high-frequency sampling. Environ. Microbiol. 17, 2459-2476. doi: 10.1111/ 1462-2920.12720

Ludwig, W., Strunk, O., Westram, R., Richter, L., Meier, H., Yadhukumar, et al. (2004). ARB: a software environment for sequence data. Nucleic Acids Res. 32, 1363-1371. doi: 10.1093/nar/gkh293

Manz, W., Amann, R., Ludwig, W., Wagner, M., and Schleifer, K.-H. (1992). Phylogenetic oligonucleotide probes for the major subclasses of proteobacteria: problems and solutions. Syst. Appl. Microbiol. 15, 593-600. doi: 10.1016/S07232020(11)80121-9

McCarren, J., Becker, J. W., Repeta, D. J., Shi, Y., Young, C. R., Malmstrom, R. R., et al. (2010). Microbial community transcriptomes reveal microbes and metabolic pathways associated with dissolved organic matter turnover in the sea. PNAS 107, 16420-16427. doi: 10.1073/pnas.1010732107

Migula, W. (1895). "Bacteriaceae (Stäbchenbacterien)," in Die Natürlichen Pflanzenfamilien, eds T. I. Abteilung Ia and A. Engler (Leipzig: W. Engelmann), 20-30.

Morán, X. A. G., Sebastián, M., Pedrís-Alií, C., and Estrada, M. (2006). Response of Southern Ocean phytoplankton and bacterioplankton production to shortterm experimental warming. Limnol. Oceanogr. 51, 1791-1800. doi: 10.4319/lo. 2006.51.4.1791

Mou, X., Sun, S., Edwards, R. A., Hodson, R. E., and Moran, M. A. (2008). Bacterial carbon processing by generalist species in the coastal ocean. Nature 451, 708-711. doi: 10.1038/nature06513

Müren, U., Berglund, J., Samuelsson, K., and Andersson, A. (2005). Potential effects of elevated sea-water temperature on pelagic food webs. Hydrobiologia 545, 153-166. doi: 10.1007/s10750-005-2742-4

Nichols, D. S., Greenhill, A. R., Shadbolt, C. T., Ross, T., and McMeekin, T. A. (1999). Physicochemical parameters for growth of the sea ice bacteria Glaciecola punicea ACAM 611T and Gelidibacter sp. strain IC158. Appl. Environ. Microbiol. 65, 3757-3760.

Pedler, B. E., Aluwihare, L. I., and Azam, F. (2014). Single bacterial strain capable of significant contribution to carbon cycling in the surface ocean. PNAS 111, 7202-7207. doi: 10.1073/pnas.1401887111

Pernthaler, A., Pernthaler, J., and Amann, R. (2002). Fluorescence in situ hybridization and catalyzed reporter deposition for the identification of marine bacteria. Appl. Environ. Microbiol. 68, 3094-3101. doi: 10.1128/AEM.68.6.30943101.2002

Pernthaler, J., and Amann, R. (2005). Fate of heterotrophic microbes in pelagic habitats: focus on populations. Microbiol. Mol. Biol. Rev. 69, 440-461. doi: 10.1128/MMBR.69.3.440-461.2005

Petchey, O. L., McPhearson, P. T., Casey, T. M., and Morin, P. J. (1999). Environmental warming alters food-web structure and ecosystem function. Nature 402, 69-72. doi: 10.1038/47023

Peters, F. (2002). Overcoming linearisation errors in calculating bacterial growth rates. Mar. Ecol. Prog. Ser. 245, 305-308. doi: 10.3354/meps 245305
Pinhassi, J., Sala, M. M., Havskum, H., Peters, F., Guadayol, Ò, Malits, A., et al. (2004). Changes in bacterioplankton composition under different phytoplankton regimens. Appl. Environ. Microbiol. 70, 6753-6766. doi: 10.1128/ AEM.70.11.6753-6766.2004

Pomeroy, L. R., and Deibel, D. (1986). Temperature regulation of bacterial activity during the spring bloom in newfoundland coastal waters. Science 233, 359-361. doi: 10.1126/science.233.4761.359

Prabagaran, S. R., Manorama, R., Delille, D., and Shivaji, S. (2007). Predominance of Roseobacter, Sulfitobacter, Glaciecola and Psychrobacter in seawater collected off Ushuaia, Argentina, Sub-Antarctica. FEMS Microbiol. Ecol. 59, 342-355.

Qin, Q.-L., Xie, B.-B., Yu, Y., Shu, Y.-L., Rong, J.-C., Zhang, Y.-J., et al. (2014). Comparative genomics of the marine bacterial genus Glaciecola reveals the high degree of genomic diversity and genomic characteristic for cold adaptation. Environ. Microbiol. 16, 1642-1653. doi: 10.1111/1462-2920.12318

Quast, C., Pruesse, E., Yilmaz, P., Gerken, J., Schweer, T., Yarza, P., et al. (2013). The SILVA ribosomal RNA gene database project: improved data processing and web-based tools. Nucleic Acids Res. 41, D590-D596. doi: 10.1093/nar/gks1219

Romanova, N. D., and Sazhin, A. F. (2010). Relationships between the cell volume and the carbon content of bacteria. Oceanology 50, 522-530. doi: 10.1134/ S0001437010040089

Salcher, M. M., Posch, T., and Pernthaler, J. (2013). In situ substrate preferences of abundant bacterioplankton populations in a prealpine freshwater lake. ISME J. 7, 896-907. doi: 10.1038/ismej.2012.162

Sapp, M., Wichels, A., Wiltshire, K. H., and Gerdts, G. (2007). Bacterial community dynamics during the winter-spring transition in the North Sea. FEMS Microbiol. Ecol. 59, 622-637. doi: 10.1111/j.1574-6941.2006.00238.x

Sarmento, H., and Gasol, J. M. (2012). Use of phytoplankton-derived dissolved organic carbon by different types of bacterioplankton. Environ. Microbiol. 14, 2348-2360. doi: 10.1111/j.1462-2920.2012.02787.x

Shivaji, S., and Reddy, G. S. (2014). Phylogenetic analyses of the genus Glaciecola: emended description of the genus Glaciecola, transfer of Glaciecola mesophila, G. agarilytica, G. aquimarina, G. arctica, G. chathamensis, G. polaris and G. psychrophila to the genus Paraglaciecola gen. nov. as Paraglaciecola mesophila comb. nov., P. agarilytica comb. nov., P. aquimarina comb. nov., P. arctica comb. nov., P. chathamensis comb. nov., $P$. polaris comb. nov. and $P$. psychrophila comb. nov., and description of Paraglaciecola oceanifecundans sp. nov., isolated from the Southern Ocean. Int. J. Syst. Evol. Microbiol. 64, 3264-3275. doi: 10.1099/ijs.0.065409-0

Sintes, E., Witte, H., Stodderegger, K., Steiner, P., and Herndl, G. J. (2013). Temporal dynamics in the free-living bacterial community composition in the coastal North Sea. FEMS Microbiol. Ecol. 83, 413-424. doi: 10.1111/1574-6941. 12003

Sommer, U., Aberle, N., Engel, A., Hansen, T., Lengfellner, K., Sandow, M., et al. (2007). An indoor mesocosm system to study the effect of climate change on the late winter and spring succession of Baltic Sea phyto- and zooplankton. Oecologia 150, 655-667. doi: 10.1007/s00442-0060539-4

Tada, Y., Taniguchi, A., Nagao, I., Miki, T., Uematsu, M., Tsuda, A., et al. (2011). Differing growth responses of major phylogenetic groups of marine bacteria to natural phytoplankton blooms in the western North Pacific Ocean. Appl. Environ. Microbiol. 77, 4055-4065. doi: 10.1128/AEM.02952-10

Teeling, H., Fuchs, B. M., Becher, D., Klockow, C., Gardebrecht, A., Bennke, C. M., et al. (2012). Substrate-controlled succession of marine bacterioplankton populations induced by a phytoplankton bloom. Science 336, 608-611. doi: $10.1126 /$ science. 1218344

Teira, E., Reinthaler, T., Pernthaler, A., Pernthaler, J., and Herndl, G. J. (2004). Combining catalyzed reporter deposition-fluorescence in situ hybridization and microautoradiography to detect substrate utilization by bacteria and Archaea in the deep ocean. Appl. Environ. Microbiol. 70, 4411-4414. doi: 10. 1128/AEM.70.7.4411-4414.2004

van Trappen, S., Tan, T.-L., Yang, J., Mergaert, J., and Swings, J. (2004). Glaciecola polaris sp. nov., a novel budding and prosthecate bacterium from the Arctic Ocean, and emended description of the genus Glaciecola. Int. J. Syst. Evol. Microbiol. 54, 1765-1771. doi: 10.1099/ijs.0.02862-0

von Scheibner, M., Dörge, P., Biermann, A., Sommer, U., Hoppe, H.-G., and Jürgens, K. (2014). Impact of warming on phyto-bacterioplankton coupling and bacterial community composition in experimental mesocosms. Environ. Microbiol. 16, 718-733. doi: 10.1111/1462-2920.12195 
Wallner, G., Amann, R., and Beisker, W. (1993). Optimizing fluorescent in situ hybridization with rRNA-targeted oligonucleotide probes for flow cytometric identification of microorganisms. Cytometry 14, 136-143. doi: 10.1002/cyto. 990140205

Winder, M., Berger, S. A., Lewandowska, A. M., Aberle, N., Lengfellner, K., Sommer, U., et al. (2012). Spring phenological responses of marine and freshwater plankton to changing temperature and light conditions. Mar. Biol. 159, 2491-2501. doi: 10.1007/s00227-012-1964-z

Wohlers, J., Engel, A., Zöllner, E., Breithaupt, P., Jürgens, K., Hoppe, H.-G., et al. (2009). Changes in biogenic carbon flow in response to sea surface warming. PNAS 106, 7067-7072. doi: 10.1073/pnas.0812743106

Wohlers-Zöllner, J., Biermann, A., Engel, A., Dörge, P., Lewandowska, A. M., von Scheibner, M., et al. (2012). Effects of rising temperature on pelagic biogeochemistry in mesocosm systems. A comparative analysis of the AQUASHIFT Kiel experiments. Mar. Biol. 159, 2503-2518.

Worden, A. Z., Seidel, M., Smriga, S. P., Wick, A., Malfatti, F., Bartlett, D., et al. (2006). Trophic regulation of Vibrio cholerae in coastal marine waters. Environ. Microbiol. 8, 21-29. doi: 10.1111/j.1462-2920.2005.00863.x
Zeder, M., Peter, S., Shabarova, T., and Pernthaler, J. (2009). A small population of planktonic Flavobacteria with disproportionally high growth during the spring phytoplankton bloom in a prealpine lake. Environ. Microbiol. 11, 2676-2686. doi: 10.1111/j.1462-2920.2009.01994.x

Zhang, D.-C., Yu, Y., Chen, B., Wang, H.-X., Liu, H.-C., Dong, X.-Z., et al. (2006). Glaciecola psychrophila sp. nov., a novel psychrophilic bacterium isolated from the Arctic. Int. J. Syst. Evol. Microbiol. 56, 2867-2869. doi: 10.1099/ijs.0.64575-0

Conflict of Interest Statement: The authors declare that the research was conducted in the absence of any commercial or financial relationships that could be construed as a potential conflict of interest.

Copyright (c) 2017 von Scheibner, Sommer and Jürgens. This is an open-access article distributed under the terms of the Creative Commons Attribution License (CC BY). The use, distribution or reproduction in other forums is permitted, provided the original author(s) or licensor are credited and that the original publication in this journal is cited, in accordance with accepted academic practice. No use, distribution or reproduction is permitted which does not comply with these terms. 